\title{
PERAN PARA PIHAK DALAM HUBUNGAN KERJA PEKERJA OUTSOURCING YANG MENJADIKAN HUBUNGAN KERJA HARMONIS
}

\author{
SITI HANAH ${ }^{1}$, NUR ASMILIA ${ }^{2}$ \\ Prodi Akuntansi S1, Fakultas Ekonomi, Universitas Pamulang \\ *Email : titi.hanah@gmail.com; nurasmilia30@gmail.com
}

\begin{abstract}
This paper discusses "Employment work relations outsourcing", is one important factor in running the company wheels. This paper examines the work relations of $H R$ very influential on company performance which ultimately inline to the company's revenue and profit (margin). In this paper the authors use the concept of employment relations OUTSOURCING workers are employed, THROUGH "SERVICE / JOB CONTRACT" or "MANPOWER SUPPLY / BODY SHOP, to examine in depth and identify both in terms of law, basic conditions, impacts both for workers and companies, rights and rights the obligations of each party, termination of employment.
\end{abstract}

Keywords: Employee relations with harmonious employers

\section{PENDAHULUAN}

Pengkajian mengenai PEKERJA merupakan salah satu hal yang cukup menarik untuk dibahas dalam mempelajari ilmu manajemen Sumber Daya Manusia (SDM)/Pekerja . Peraturan pemerintah di Indonesia yang masih abu-abu dan ketidak tegasan hukum yang pada akhirnya akan memberikan dampak kerugian baik bagi pekerja maupun perusahaan, adapun yang melatar belakangi penelitian ini adalah :

1. Tenaga kerja sebagai salah satu faktor dalam proses produksi turut dipengaruhi oleh sirklus kinerja dan performance perusahaan yang pada akhirnya berpengaruh kepada revenue dan margin perusahaan

2. Tiap2 warga negara berhak atas pekerja dan penghidupan yg layak bagi kemanusian amanat dari pasal 27 ayat 2 uu dasar negara RI th 1945.

3. UU No 13 th 2003 tentang ketenagakerjaan yang berbunyi wajib memperdayakan tenaga kerja secara optimal namun manusiawi .

4. Putusan Mahkamah Konstitusi No. 27/PUU-IX/2011 tanggal 17 Januari 2012.

5. Tuntutan masyarakat mengenai pelaksanaan outsourcing.

6. kelompok angkatan kerja , sebagai penduduk yg sudah memasuki usia kerja, baik yg sdh bekerja, maupun yg belum bekerja atau mencari kerja. Didlmnya terdapat kelompok pengangguran terbuka/penuh, pengangguran 
tidak kentara/setengah pengangguran berdasarkan produktivitas maupun penghasilan

7. Kelompok orang yang pemenuhan kebutuhan hidupnya masih harus menjadi tangungan orang lain (kelompok angkatan kerja, khususnya pekerja/buruh).

Selanjutnya, Untuk mengatasi dari kondisi tsb pemerintah perlu menetapkan kebijakan terkait perluasan kesempatan kerja.

Dengan pertumbuhan angkatan kerja yang cukup signifikan dimana lapangan kerja di Indonesia belum dapat menampung seluruh lulusan, maka hal ini menjadi masalah besar pemerintah dalam memenuhi kebutuhan masyarakat akan pekerjaan. Seiring dengan hal tersebut dan banyak perusahaan yang tidak mau dipusingkan oleh tuntutan pekerja yang akhir-akhir ini marak di Indonesai, maka perusahaan lebih memilih melakukan ekpansi kepada Core bisnisnya, berbanding dengan di repotkan oleh pekerja.

Seiring dengan hal tersebut diatas, tumbuh kembanglah perusahaan outsourching di Indonesia yang melakukan jasa untuk meyediakan dan memaintanance pekerja. Mereka kadang lupa bahwa pekerja tersebut adalah manusia bukan mesin, walau dari awal sudah dijelaskan tentang aturan mainnya, namun seiring dengan waktu dan kebutuhan hidup mereka tidak puas dan akhirnya mengarah ke Demo yang akhir-akhir ini marak di Indonesa. Sehubungan dengan hal tersebut banyak investor asing yang awalnya melakukan bisnis di Indonesia, akhirnya beralih ke negara lain khususnya Vietnam. Jika hal ini terus menerus dilakukan pembiaran, maka Indonesa akan kehilangan investor asing yang akan membangun pabrik atau membuka bisnis di Indonesia dan bisa jadi pebisnis Indonesia jika melihat peluang bisnis di negara lain lebih menjanjikan, maka pebisnis lokalpun akan hengkang dari tanah airnya. Berdasarkan permasalahan yang telah diuraikan tersebut, maka pokok permasalahan yang akan dibahas di dalam tulisan ini adalah : Bagaimana meyelaraskan hubungan kerja pekerja outsoursing menjadi lebih harmonis dan meberikan win win solution untuk antara para pihak, yang akhirnya berpengaruh terhadap ke harmonisan pekerjaan dan perusahaan?

\section{LANDASAN TEORI DAN HIPOTESIS}

Apa itu Pekerjaan Alih Daya (Outsourcing)?

Outsourcing atau alih daya adalah pemanfaatan tenaga kerja dengan cara memborongkan atau memindahkan tugas dan tanggung jawab pekerjaan atau kegiatan perusahaan dari perusahaan induk yang tadinya dikelola sendiri kepada perusahaan lain sebagai penyedia tenaga kerja dalam bentuk ikatan kontrak kerja sama.

Ketentuan mengenai outsourcing diatur dalam Pasal 64 sd 66 UndangUndang Nomor 13 Tahun 2003 tentang Ketenagakerjaan yang menyatakan suatu perjanjian kerja yang dibuat antara pengusaha dengan tenaga kerja, dimana 
perusahaan tersebut dapat menyerahkan sebagian pelaksanaan pekerjaan kepada perusahaan lainnya melalui perjanjian pemborongan pekerjaan yang dibuat secara tertulis.

Berikut ini beberapa pengertian dan definisi outsourcing dari beberapa sumber referensi:

Menurut Husni (2003:177), outsourcing adalah pemanfaatan tenaga kerja untuk memproduksi atau melaksanakan suatu pekerjaan oleh suatu perusahaan, melalui perusahaan penyedia/pengerah tenaga kerja.

1. Menurut Jehani (2008:1), outsourcing merupakan bentuk penyerahan pekerjaan tertentu suatu perusahaan kepada pihak ketiga yang dilakukan dengan tujuan untuk mengurangi beban perusahaan tersebut.

2. Menurut Tunggal (2009:308), Outsourcing adalah pemindahan atau pendelegasian beberapa proses bisnis kepada suatu badan penyedia jasa, dimana badan penyedia jasa tersebut melakukan proses administrasi dan manajemen berdasarkan definisi serta kreteria yang telah disepakati oleh para pihak.

3. Menurut Soewondo (2003), Outsourcing adalah pendelegasian operasi dan manajemen harian dari suatu proses bisnis kepada pihak luar (perusahaan jasa Outsourcing).

4. Menurut Tambusai (2004), Outsourcing adalah memborongkan satu bagian atau beberapa bagian dari kegiatan perusahaan yang tadinya dikelola sendiri kepada perusahaan lain.

\section{Jenis-jenis Pekerjaan Outsourcing}

Pelaksanaan pekerjaan Alih Daya (Outsourcing) dilakukan dengan dua cara, yaitu dengan pemborongan pekerjaan kepada perusahaan yang ditunjuk atau dengan penyediaan jasa pekerja/buruh kepada perusahaan lain.

Undang-Undang Nomor 13 Tahun 2003 Pasal 64 menjelaskan pengaturan menyerahkan sebagian pekerjaan kepada perusahaan lain, atau penyediaan pekerja/buruh oleh perusahaan lain dengan ketentuan pekerja/buruh harus tidak dirugikan akibat dari setiap sistem penyerahan kerja kepada pihak luar yang dilakukan oleh perusahaan utama.

Adapun jenis pekerjaan yang diperbolehkan diserahkan kepada pihak luar dengan sistem outsourcing adalah sebagai berikut:

1. Pekerjaan yang dilakukan secara terpisah dari kegiatan utama.

2. Pekerjaan yang dilakukan dengan perintah langsung atau tidak langsung oleh pemberi pekerjaan.

3. Pekerjaan yang merupakan kegiatan penunjang perusahaan secara keseluruhan.

4. Pekerjaan yang tidak menghambat proses produksi secara langsung. 


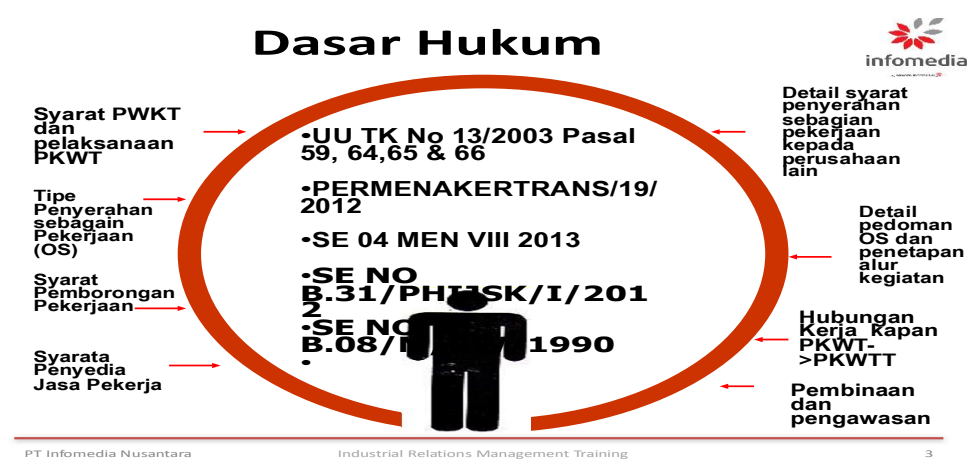

Gambar 2.1

Dasar Hukum Outsourcing

1) Undang-Undang Nomor 13 Tahun 2003 tentang Ketenagakerjaan (Pasal 64, 65 dan 66).

2) Permenakertrans Nomor 19 Tahun 2012 tentang Syarat-Syarat Penyerahan sebagian pelaksanaan Pekerjaan Kepada Perusahaan Lain.

\section{Outsourcing}

1. DEFINISI (UU13/2003)

2. Menyerahkan sebagian pelaksanaan pekerjaan kepada perusahaan lainnya melalui perjanjian pemborongan pekerjaan (tidak relevan lagi) atau penyediaan jasa pekerja yang dibuat secara tertulis

3. Ref. UU 13/2003, pasal 64-66

4. Kep. 101/Men/2004 dan Kep 220/Men/2004

5. Permenakertrans No 19 Tahun 2012

Syarat Dasar Outsourcing berdasar Ref. UU 13/2003 pasal 65, Permen No 19 Tahun 2012:

1. Pekerjaan dilakukan secara terpisah dari kegiatan utama

2. Merupakan kegiatan penunjang, dan tidak menghambat proses produksi secara langsung.

Pelanggaran dari ketentuan diatas, mengakibatkan status hubungan kerja, berubah, dari pekerja kontraktor menjadi pekerja perusahaan (dengan status hubungan kerja yang sama)

Pertanyaan:

1. Siapa yang dapat/berhak menentukan yang mana kegiatan utama dan yang mana penunjang?

2. Apakah Disnaker berhak atau kompeten menyetujui/tidak menyetujui alur kegiatan yang ditentukan Perusahaan?

Hal- hal seperti ini yang kami informasikan bahwa di Indonesia hukumnya masih abu-abu sehingga hal ini berpotensi untuk terjadi konflik antara para pihak. 


\section{Outsourcing - Objective}

1. Perusahaan dapat fokus pada kegiatan utama (core activities)

2. Mengurangi 'headache' dalam kompleksitas administrasi,

3. Tidak perlu melakukan investasi yang tidak secara mutlak diperlukan (salah satunya biaya pendidikan/sertifikasi)

4. Dapat menggunakan technical expertise (globally updated) yang tidak tersedia internal dan dapat dipekerjakan hanya pada saat diperlukan (short term)

5. Memberi kesempatan berusaha kepada Perusahaan Lokal.

Kebijakan Outsourcing diterapkan karena kebijakan tersebut dinilai dapat memberikan beberapa keuntungan bagi perusahaan, antara lain yaitu sebagai berikut (Asmawan dkk, 2014:11):

1. Fokus pada kompetensi jalur bisnis utama

Dengan melakukan Outsourcing, perusahaan dapat fokus pada bisnis utama (core business) mereka. Hal ini dapat dilakukan dengan memperbaharui strategi dan merestrukturisasi sumber daya yang ada. Perusahaan akan mendapatkan keuntungan dengan memfokuskan sumber daya ini untuk memenuhi kebutuhan pelanggan dan meningkatkan keuntungan perusahaan, dengan cara mengalihkan pekerjaan penunjang di luar bisnis utama perusahaan kepada vendor Outsourcing.

2. Penghematan dan Pengendalian Biaya Operasional

Salah satu alasan utama melakukan Outsourcing adalah peluang untuk mengurangi dan mengontrol biaya operasional. Perusahaan yang mengelola SDM-nya sendiri akan memiliki struktur pembiayaan yang lebih besar daripada perusahaan yang menyerahkan pengelolaan SDM-nya kepada vendor outsourcing. Hal ini terjadi karena vendor Outsourcing bermain dengan economics of scale dalam mengelola SDM.

3. Memanfaatkan Kompetensi Vendor Outsourcing

Karena core-business-nya di bidang jasa penyediaan dan pengelolaan SDM, vendor Outsourcing memiliki sumber daya dan kemampuan yang lebih baik di bidang ini dibandingkan dengan perusahaan. Kemampuan ini didapat melalui pengalaman mereka dalam menyediakan dan mengelola SDM untuk berbagai perusahaan. Saat menjalin kerja sama dengan vendor outsourcing yang profesional, perusahaan akan mendapatkan keuntungan dengan memanfaatkan keahlian vendor outsourcing tersebut untuk menyediakan dan mengelola SDM yang dibutuhkan oleh perusahaan.

4. Perusahaan menjadi lebih ramping dan gesit dalam merespon Pasar Setiap perusahaan, baik besar maupun kecil, pasti memiliki keterbatasan sumber daya. Dengan melakukan Outsourcing, perusahaan dapat mengalihkan sumber daya yang terbatas ini dari pekerjaan-pekerjaan yang bersifat non-core dan tidak berpengaruh langsung terhadap pendapatan dan keuntungan perusahaan kepada pekerjaan-pekerjaan strategis core-business yang pada akhirnya dapat meningkatkan kepuasan pelanggan, pendapatan dan keuntungan perusahaan.

5. Mengurangi Risiko 
Dengan melakukan outsourcing, perusahaan mampu mempekerjakan lebih sedikit karyawan, dan dipilih yang intinya saja. Hal ini menjadi salah satu upaya perusahaan untuk mengurangi risiko terhadap ketidakpastian bisnis di masa mendatang. Jika situasi bisnis sedang bagus dan dibutuhkan lebih banyak karyawan, maka kebutuhan ini tetap dapat dipenuhi melalui Outsourcing.

6. Meningkatkan Efisiensi dan Perbaikan pada Pekerjaan-Pekerjaan yang Sifatnya Non-Core Business

Saat ini banyak sekali perusahaan yang memutuskan untuk mengalihkan setidaknya satu pekerjaan non-core mereka dengan berbagai alasan. Mereka umumnya menyadari bahwa merekrut dan mengontrak karyawan, menghitung dan membayar gaji, lembur dan tunjangan-tunjangan, memberikan pelatihan, administrasi umum serta memastikan semua proses berjalan sesuai dengan peraturan perundangan adalah pekerjaan yang rumit, banyak membuang waktu, pikiran dan dana yang cukup besar.

\section{Kelebihan dan Kelemahan Outsourcing}

Menurut Ropikhin (2010), penggunaan tenaga kerja dengan sistem alih daya atau outsourcing memiliki kelebihan dan kelemahan, yaitu sebagai berikut:

1. Kelebihan outsourcing

2) Meningkatkan fokus bisnis perusahaan.

3) Masuk pada kemampuan kelas dunia.

4) Mempercepat keuntungan dari re-engineering (teknologi baru).

5) Membagi risiko usaha.

6) Menggunakan sumber yang ada untuk aktivitas yang lebih strategis.

1. Kelemahan outsourcing

1) Perusahaan dapat kehilangan keterampilan kritikal atau mengembangkan ketrampilan yang salah, tidak sesuai dengan dengan kompetensi inti.

2) Perusahaan dapat kehilangan keterampilan lintas fungsional, karena adanya penugasan kepada pihak lain.

3) Perusahaan dapat kehilangan kendali atau pengawasan pada pemasok.

4) Organisasi perusahaan menjadi sangat tergantung pada pihak vendor atas bentuk kegiatan dan sejumlah harga yang ditawarkan kepada perusahaan.

\section{Outsourcing - Dampak}

1. Tidak perlu memikirkan pengembangan/karir Pekerja

2. Upah tidak harus/tidak perlu mengikuti salary structure yang diberlakukan bagi pekerja perusahaan

3. Tunjangan/isentif/bonus tidak harus sama

4. Kenaikan biaya $\mathrm{C} \& \mathrm{~B}$ untuk project jangka pendek

5. Penurunan biaya $\mathrm{C} \& \mathrm{~B}$ untuk poject jangka panjang

6. Biaya tenaga kerja bisa meningkat, karena overhead Kontraktor $\rightarrow$ sebaiknya objective outsourcing tidak dikaitkan secara langsung untuk 'cost cutting'. 


\section{Outsourcing - Syarat Perusahaan Jasa}

1. Berbadan Hukum dan Mempunyai Ijin Usaha Outsourcing (Permen No 19 Tahun 2012).

2. Membuat Perjanjian Kerja dengan Pekerjanya.

3. Memberikan fasilitas kesehatan dan pengobatan serta kesejahteraan lainnya seperti yang tercantuk dalam kontrak antara Pemberi kerja dengan Perusahaan Jasa dan tidak melakukam wan prestasi

4. Bertanggung jawab atas masalah hubungan industrial

5. Bersedia menerima Pekerja dari Kontraktor sebelumnya

6. Mengikut sertakan pekerjanya pada Jamsostek dan lakukan pembayaran THR, Lembur dan Pesangon, sesuai ketentuan pada kontrak atau perundang-undangan

\section{Tugas Staff Sdm}

Sebagai penanggung jawab atau advisor untuk Departemen Pengguna (User):

1. Memastikan pemenuhan ketentuan perundang-undangan (membantu bagian Hukum/Legal menyiapkan "Exhibit”);

2. Menjadi advisor dari Dept. Pengguna/User

3. Menjadi advisor dari bagian Account Payable;

4. Memberikan penjelasan saat 'pre-bid meeting';

5. Menginterview Staff SDM 'prospective bidder' bila perlu;

6. Melakukan audit atas pelaksanaan kontrak, untuk memastikan Kontraktor memenuhi kewajibannya.

7. Menjadi Mentor staff SDMnya Kontraktor.

\section{Outsourcing}

1. Pekerja outsourcing bukan pekerja Perusahaan, karena dipekerjakan (diterima bekerja) oleh Contractor

2. Hubungan kerja dengan Pekerja Perusahaan adalah hubungan atasan bawahan karena adanya pekerjaan dan perintah.

3. Tanggung jawab hubungan industrial, pada Contractor

4. Terms and conditions of employment' harus aligned dengan persyaratan yang ditentukan dalam Service Contract $\rightarrow$ upaya Perusahaan memberikan perlindungan kepada Pekerja. Perusahaan berhak melakukan audit untuk meyakinkan 'compliance' SE -08/M/BW/1990, 13 Mei 1990

5. Umumnya, terdapat perbedaan mencolok antara perlindungan dan kesejahteraan pekerja pada perusahaan yang memborongan pekerjaan dengan pekerja pada perusahaan pemborong $\rightarrow$ sehingga,

6. Perusahaan yang memborongkan pekerjaan, supaya:

7. Melakukan pembinaan dan upaya agar perlindungan dan kesejahteraan tidak jauh berbeda,

8. Dalam setiap pejanjian pemborongan pekerjaan supaya dicantumkan bentuk dan tingkat upah serta kesejahteraan lainnya yang harus menjadi tanggung jawab pemborong

9. Mengawasi pelaksanaan Surat Perjanjian Pemborongan Pekerjaan termasuk segi perlindungan,pengupahan dan kesejahteraan tenaga kerja. 
Perusahaan dapat menyerahkan sebagian pelaksanaan pekerjaan kepada perusahaan lain melalui:

1. Perjanjian pemborongan pekerjaan, atau

2. Penyediaan jasa pekerja/buruh.

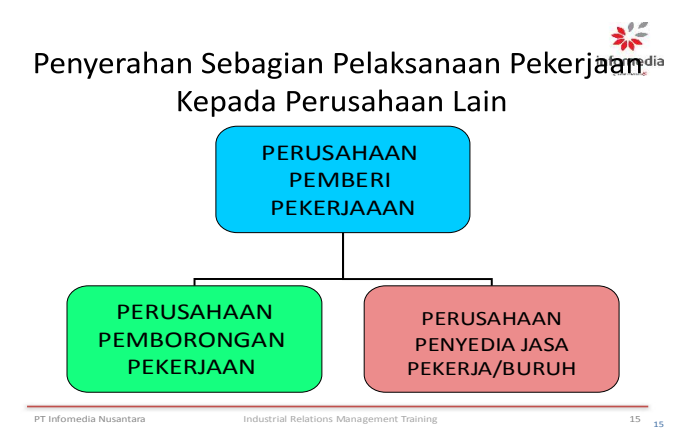

Gambar 2.2

Penyerahan Sebagian Pelaksanaan Pekerjaan

Perusahaan penerima pemborongan harus memenuhi persyaratan:

1. Berbentuk badan hukum

2. Memiliki tanda daftar perusahaan

3. Memiliki izin usaha

4. Memiliki bukti wajib lapor ketenagakerjaan di perusahaan

Kewajiban Asosiasi Sektor Usaha :

1. Membuat alur kegiatan proses pelaksanaan pekerjaan sesuai sektor usaha masing-masing.

2. Alur harus menggambarkan proses pelaksanaan pekerjaan dari awal sampai akhir serta memuat kegiatan utama dan kegiatan penunjang.

3. Alur sebagai dasar bagi perusahan pemberi pekerjaan untuk memborongkan pekerjaan.

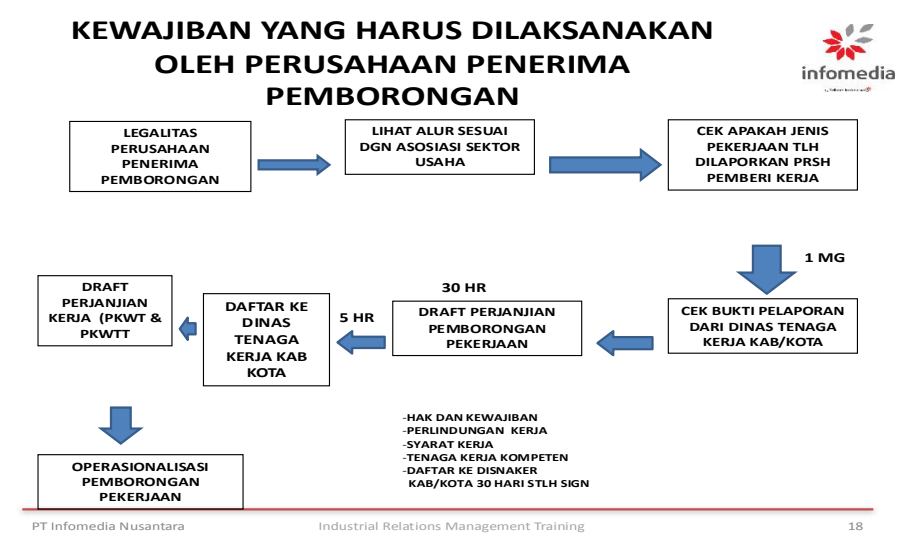

Gambar 2.3

Kewajiban Pemborong 
Kewajiban perusahaan yang akan memborongkan pekerjaan :

1. Melaporkan jenis pekerjaan penunjang yang akan diserahkan berdasarkan alur yang ditetapkan assosiasi sektor kepada instansi yang bertanggung jawab di bidang ketenagakerjaan kabupaten/kota.

2. Menyampaikan setiap perubahan jenis pekerjaan penunjang yang akan diborongkan kepada instansi yang bertanggung jawab di bidang ketenagakerjaan kabupaten/kota.

3. Membuat perjanjian pemborongan pekerjaan secara tertulis.

4. Perjanjian pemborongan sekurang-kurangnya memuat:

5. Hak dan kewajiban masing-masing pihak.

6. Menjamin terpenuhinya perlindungan kerja dan syarat-syarat kerja bagi pekerja/buruh.

7. Memiliki tenaga kerja yang kompetensi di bidangnya.

Kewajiban Perusahaan Pemborong Pekerjaan

1. Menandatangani perjanjian pemborongan.

2. 30 (tiga puluh) hari kerja sebelum pekerjaan dilaksanakan, perusahaan pemborongan pekerjaan harus mendaftarkan perjanjian pemborongan kepada instansi yang bertanggung jawab di bidang ketenagakerjaan kabupaten/kota tempat pemborongan pekerjaan dilaksanakan.

3. Membuat perjanjian kerja secara tertulis yang memuat:

1) menjamin terpenuhinya hak-hak pekerja/buruh sebagaimana diatur dalam peraturan perundang-undangan.

2) Perjanjian Kerja pemborongan dibuat secara tertulis.

3) jenis hubungan kerja PKWT atau PKWTT.

Kewajiban Instansi Ketenagakerjaan Kabupaten/Kota

1. Mengeluarkan bukti pelaporan jenis pekerjaan penunjang yang akan diborongkan paling lambat 1 (satu) minggu sejak pelaporan dilaksanakan oleh perusahaan pemberi pekerjaan.

2. Menerbitkan bukti pendaftaran perjanjian pemborongan paling lambat 5 (lima) hari kerja sejak berkas permohonan pendaftaran perjanjian diterima.

3. Pelaporan jenis kegiatan dan pendaftaran perjanjian pemborongan pekerjaan tidak dikenakan biaya.

4. Pendaftaran perjanjian pemborongan tidak dikenakan biaya.

\section{Larangan}

1. Larangan perusahaan pemberi pekerjaan menyerahkan pelaksanaan pekerjaan tanpa bukti pelaporan.

2. Perusahaan pemberi pekerjaan menyerahkan pelaksanaan pekerjaan tanpa bukti pelaporan, hubungan kerja antara pekerja/buruh dengan perusahaan penerima pemborongan beralih kepada perusahaan pemberi pekerjaan.

3. Menyerahkan pelaksanaan pekerjaan kepada perusahaan pemborong yang tidak berbadan hukum hubungan kerja pekerja/buruh beralih kepada perusahaan pemberi pekerjaan 
Penyediaan Jasa Pekerja/Buruh

1. Perusahaan pemberi pekerjaan dapat menyerahkan sebagian pelaksanaan pekerjaan melalui penyedia jasa pekerja/buruh yang dibuat secara tertulis.

2. Pekerjaan yang diserahkan merupakan kegiatan jasa penunjang atau tidak berhubungan langsung dengan proses produksi.

3. Kegiatan jasa penunjang yang dapat dilakukan oleh perusahaan meliputi:

4. usaha pelayanan kebersihan (cleaning service);

5. usaha penyediaan makanan bagi pekerja/buruh (catering);

6. usaha tenaga pengaman (security/satuan pengamanan);

7. usaha jasa penunjang di pertambangan dan perminyakan; dan

8. usaha penyediaan angkutan bagi pekerja/buruh

9. Perusahaan penyedia jasa pekerja/buruh harus memenuhi persyaratan:

1) berbentuk badan hukum Perseroan Terbatas (PT) yang didirikan berdasarkan peraturan perundang-undangan;

2) memiliki tanda daftar perusahaan;

3) memiliki izin usaha;

4) memiliki bukti wajib lapor ketenagakerjaan di perusahaan;

5) memiliki izin operasional dari instansi yang bertanggungjawab di bidang ketenagakerjaan provinsi;

6) mempunyai kantor dan alamat tetap; dan

7) memiliki Nomor Pokok Wajib Pajak (NPWP) atas nama perusahaan.

\section{Prosedur Izin Operasional}

Perusahaan penyedia jasa pekerja/buruh mengajukan permohonan kepada instansi yang bertanggung jawab di bidang ketenagakerjaan provinsi tempat pelaksanaan pekerjaan, dengan melampirkan:

1. copy anggaran dasar yang didalamnya memuat kegiatan usaha penyediaan jasa pekerja/buruh;

2. copy pengesahan sebagai badan hukum Perseroan Terbatas (PT);

3. copy surat ijin usaha penyediaan jasa pekerja/buruh;

4. copy tanda daftar perusahaan;

5. copy bukti wajib lapor ketenagakerjaan di perusahaan;

6. copy pernyataan kepemilikan kantor atau bukti penyewaan kantor yang ditandatangani oleh pimpinan perusahaan; dan

7. copy Nomor Pokok Wajib Pajak (NPWP) atas nama perusahaan

8. Instansi yang bertanggung jawab di bidang ketenagakerjaan provinsi, menerbitkan izin operasional terhadap permohonan yang telah memenuhi persyaratan dalam waktu paling lambat 14 (empat belas) hari kerja sejak permohonan diterima.

9. Izin operasional) berlaku di seluruh kabupaten/kota di provinsi yang bersangkutan

10. Izin operasional berlaku untuk jangka waktu 3 (tiga) tahun dan dapat diperpanjang untuk jangka waktu yang sama. 
11. Perpanjangan disetujui atau ditolak berdasarkan hasil evaluasi kinerja perusahaan yang dilakukan oleh instansi yang bertanggung jawab di bidang ketenagakerjaan kabupaten/kota.

Perjanjian Penyedia Jasa Pekerja/Buruh :

1. Perusahaan pemberi pekerjaan dan perusahaan penyedia jasa wajib membuat perjanjian Penyediaan Jasa Pekerja/Buruh secara tertulis

2. Perjanjian Penyediaan Jasa Pekerja/Buruh sekurang-kurangnya memuat:

1) jenis pekerjaan yang akan dilakukan oleh pekerja/buruh dari perusahaan penyedia jasa pekerja/buruh;

2) penegasan bahwa perusahaan penyedia jasa pekerja/buruh bersedia menerima pekerja/buruh dari perusahaan penyedia jasa pekerja/buruh sebelumnya untuk jenis pekerjaan yang terus menerus ada di perusahaan pemberi pekerjaan dalam hal terjadi penggantian perusahaan penyedia jasa pekerja/buruh; dan

3) hubungan kerja antara perusahaan penyedia jasa pekerja/buruh dengan pekerja/buruh yang dipekerjakannya berdasarkan perjanjian kerja waktu tidak tertentu atau perjanjian kerja waktu tertentu

4) Perusahaan penyedia jasa pekerja/buruh tidak dapat melakukan operasional pekerjaannya sebelum mendapatkan bukti pendaftaran PPJP dari instansi yang bertanggung jawab di bidang ketenagakerjaan kabupaten/kota tempat pekerjaan dilaksanakan.

5) Perusahaan penyedia jasa pekerja/buruh melakukan pekerjaan yang tidak mendaftar PPJP, maka izin operasional dicabut oleh instansi ket-an provinsi berdasarkan rekomendasi instansi ket-an kabupaten/kota.

6) Izin operasional dicabut, perusahaan penyedia jasa pekerja/buruh tetap bertanggung jawab memenuhi hak-hak pekerja/buruh yang bersangkutan

7) Perjanjian Penyedia jasa pekerja/buruh didaftarkan kepada instansi yang bertanggungjawab di bidang ketenagakerjaan kabupaten/kota tempat pekerjaan dilaksanakan.

8) Pendaftaran Perjanjian Penyedia jasa pekerja/buruh paling lambat 30 hari setelah ditandatangani para pihak dengan melampirkan:

9) izin operasional perusahaan Penyedia jasa pekerja/buruh yang masih berlaku; dan

10) draft perjanjian kerja.

11) Pendaftaran tidak dikenakan biaya.

12) Instansi yang bertanggung jawab di bidang ketenagakerjaan kabupaten/kota tempat pekerjaan dilaksanakan menerbitkan bukti pendaftaran PPJP paling lambat 7 (tujuh) hari kerja sejak berkas permohonan pendaftaran perjanjian diterima (lengkap).

13) Pejabat yang bertanggung jawab di bidang ketenagakerjaan kabupaten/kota dapat menolak pendaftaran PPJP dengan alasan atas permohonan yang tidak sesuai. 
Perjanjian Kerja Penyediaan Jasa Pekerja/Buruh

1. Perusahaan penyedia jasa pekerja/buruh wajib membuat perjanjian kerja secara tertulis dengan pekerja/buruh.

2. Perjanjian kerja dapat berupa PKWT atau PKWTT.

3. PKWT yang objek kerjanya tetap ada sekurang-kurangnya harus memuat: Jaminan Kelangsungan Kerja, Jaminan Terpenuhinya Hak-Hak Pekerja, dan Jaminan Perhitungan Masa Kerja.

4. Perjanjian kerja harus dicatatkan kepada instansi yang bertanggung jawab di bidang ketenagakerjaan kabupaten/kota tempat pekerjaan dilaksanakan.

5. Perjanjian kerja tidak dicatatkan, izin operasional dicabut instansi yang bertanggung jawab di bidang ketenagakerjaan provinsi berdasarkan rekomendasi dari instansi yang bertanggung jawab di bidang ketenagakerjaan kabupaten/kota.

Kewajiban Instansi Yang Bertanggungjawab Di Bidang Ketenagakerjaan Kabupaten/Kota :

1. Menerbitkan bukti pendaftaran perjanjian penyedia jasa pekerja/ buruh paling lambat 7 hari sejak permohonan pendaftaran perjanjian diterima.

2. Dapat menolak atau menyetujui permohonan pendaftaran perjanjian penyedia jasa pekerja/buruh yang tidak sesuai dengan memberi alasan.

3. Pendaftaran perjanjian penyedia jasa pekerja/buruh kerja tidak dikenakan biaya.

4. Mencabut izin operasional perusahaan penyedia jasa pekerja/buruh berdasarkan rekomendasi instansi terkait di kabupaten/kota.

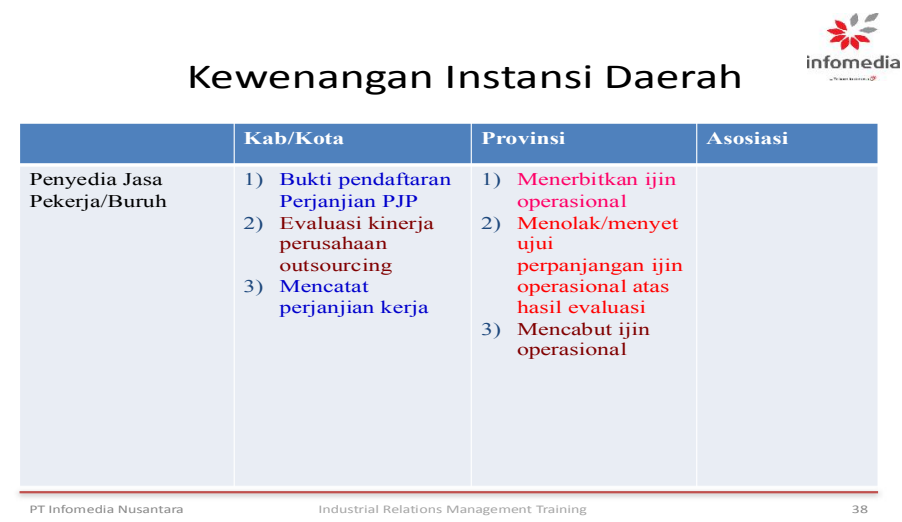

Gambar 2.4

Kewenangan Instansi Daerah

Hak-hak pekerja/buruh meliputi:

1. hak-hak atas cuti apabila telah memenuhi syarat masa kerja;

2. hak atas jaminan sosial;

3. hak atas tunjangan hari raya;

4. hak istirahat paling singkat 1 (satu) hari dalam 1 (satu) minggu; 
5. hak menerima ganti rugi dalam hal hubungan kerja diakhiri oleh perusahaan penyedia jasa pekerja/buruh sebelum perjanjian kerja waktu tertentu berakhir bukan karena kesalahan pekerja;

6. hak atas penyesuaian upah yang diperhitungkan dari akumulasi masa kerja yang telah dilalui; dan

7. hak lain yang telah diatur dalam peraturan perundang-undangan dan/atau perjanjian kerja sebelumnya

8. Dalam hal pekerja/buruh tidak memperoleh jaminan kelangsungan bekerja, maka pekerja/buruh dapat mengajukan gugatan kepada Pengadilan Hubungan Industrial.

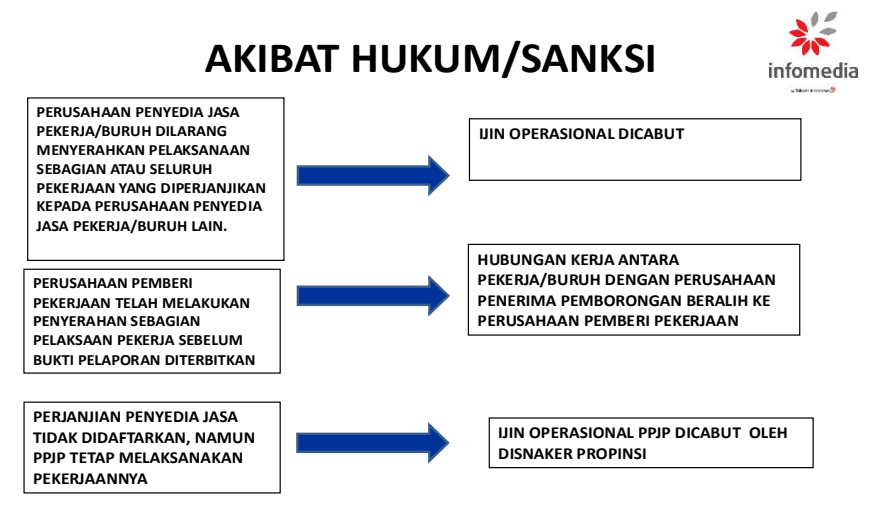

Gambar 2.5

Sanksi Hukum

\section{Pemutusan Perjanjian Penyedia Jasa Pekerja/Buruh}

Perusahaan pemberi pekerjaan tidak melanjutkan perjanjian penyediaan jasa pekerja/buruh dan mengalihkan pekerjaan penyediaan jasa pekerja/buruh kepada perusahaan penyedia jasa pekerja/buruh yang baru, maka perusahaan penyedia jasa pekerja/buruh yang baru, harus melanjutkan perjanjian kerja yang telah ada sebelumnya tanpa mengurangi ketentuan yang ada dalam perjanjian kerja yang telah disepakati.

Pengalihan pekerjaan kepada perusahaan penyedia jasa pekerja/buruh yang baru, maka masa kerja yang telah dilalui para pekerja/buruh pada perusahaan penyedia jasa pekerja/buruh yang lama harus tetap dianggap ada dan diperhitungkan oleh perusahaan penyedia jasa pekerja/buruh yang baru.

\section{METODE PENELITIAN}

Dalam penelitian ini, penulis menggunakan metode kualitatif, artinya peneliti ini akan menyajikan data dan penjelasan secara rinci mengenai fenomenafenomena social yang terjadi di sekitar kita. Penelitian dengan metode kualitatif adalah penelitian yang berupaya memahami makna dari suatu permasalahan social 
yang terjadi. Tulisan ini juga bersifat eksplanatif kerena berupaya untuk menjawab pertanyaan mengenai dampak dari adanya pekerja Outsourching yang dapat dilihat dari peran pekerja, perusahaan jasa outsourching dan perusahaan pengguna jasa outsourching dalam kebijakan pemerintah Indonesia.

Tehnik pengumpulan data kualitatif antara lain literature, observasi, dan wawancara serta mengikuti training dan pengalaman pribadi sebagai manager Industrial Relation Di PT Infomedia dalam mengelolah pekerja outsourcing. Pada penelitian ini penulis akan mengumpulkan data studi literature yang diperoleh dari beberapa sumber seperti buku, jurnal, artikel di internet, bahan training. Data-data tersebut berkaitan dengan perannya dalam hubungan kerja pekerja dan perusahaan untuk membantu penulis menjawab pertanyaan dalam penelitian.

\section{ANALISIS DATA DAN DISKUSI HASIL}

Dalam mengelola pekerja outsourcing perusahaan melakukan rasa aman baik dari sisi keamanan phisik maupun keamanan psikologis. Hal ini adanya rasa aman saat pulang dan pergi kerja, adanya jaminan keselamatan kerja dan jaminan keamanan harta benda di tempat kerja, adanya keamanan peralatan kerja. Selanjutnya jaminan psikologis adalah perlakuan yang baik dari atasan dan jajaran manajemen, adanya jaminan kesehatan, asuransi kesehatan dan asuransi tenaga kerja, dan hubungan interpersonal yang baik di tempat kerja.

Terkait pendapatan, gaji yang diterima pekerja outsourching khususnya layanan Contact Center, Receptionist, Customer Service sesuai dengan Upah minimum pekerja (UMP) didaerah dimana pekerja outsourcing ditempatkan ditambah tunjangan performance kehadiran dan performance kinerja atas prestasi yang setiap bulan dilakukan penilaian terhadap pekerja ousourcing dan uang Tunjangan hari Raya (THR). Sebagai pekerja pemula hal ini dapat dipakai sebagai pengalaman kerja untuk meningkatkan value pekerja yang pada akhirnya menambah nilai pekerja baik dimata perusahaan outsourcing maupun perusahaan yang mempekerjakan tenaga kerja tersebut atau perusahaan lain, jika hal ini dilakukan sesuai uu tenaga kerja hanya dalam jangka pendek sebagai penambah pengalaman.

\section{KESIMPULAN}

Dari hasil penelitian dan kesimpulan yang dapat diambil sebagai berikut :

Outsorcing di Indonesia merupakan system kerja kontrak yang didalamnya terdapat pemberi kerja dan pekerja dan jasa perusahaan yang mengelola outsourcing sebagai contractor dalam hal ini. Berdasarkan uu no 13 tahun 2003 memberikan dasar pertimbangan dengan uu ketenagakerjaan.

Outsourcing merupakan salah satu solusi yang paling sering digunakan untuk mengembangkan suatu system informasi pada suatu perusahaan, karena dengan outsourcing perusahaan akan lebih focus pada bisnis inti. 
Penyedia jasa outsourcing yang bertbentuk badan hukum dengan pekerja outsorcing menggunakan kerja waktu tertentu (PKWT) yang sebagian besar pada perjanjian tersebut mengacu kepada uu ketenaga kerjaan dan dasar hukum yang berlaku di Indonesia serta pekerja dan perusahaan saling menyepakati maka hal ini mumpuni untuk berlanjut selama para pihak win win.

Namun kebijakan ini hanya dapat dilakukan dalam jangka pendek, agar perusahaan dan pekerja selaras dengan tumbuh kembangnya bisnis, dan diharapkan jika perusahaan mengalami tumbuh kembang yang pesat, pekerja outsourcing ini smart dan productive serta mempunya kinerja/performance kerja yang baik akan lebih elok jika diberikan kesempatan untuk dapat menjadi pekerja tetap, karena hal ini akan membuat pekerja nyaman dan berlomba untuk meningkatkan produktifitas serta kinerja yang baik yang pada akhirnya perusahaan akan di untungkan dengan mempekerjakan pekerja yang sudah mempunyai pengalaman dan loyal terhadap perusahaan yang pada akhirnya dapat meningkatkan revenue dan margin perusahaan.

Seiring dengan waktu, pemerintah akan lebih elok jika mendukung pebisnis di Indonesia untuk menerapkan system pembayaran upah melalui produktifitas bukan UMP dimana, hal ini akan membantu perusahaan dan pekerja yang produktifitasnya tinggi lebih semangat untuk selalu meningkatkan kinerja yang pada akhirnya merangsang investor asing untuk menanamkan modal di Indonesia.

\section{REFERENSI}

Asmawan dkk. (2014). Implementasi Sistem Outsourcing dalam Perusahaan. Bogor: Institut Pertanian Bogor.

Husni, Lalu. (2003). Pengantar Hukum Ketenagakerjaan Indonesia Edisi Revisi. Jakarta: Raja Grafindo Persada.

Jehani, Libertus. 2008. Hak-Hak Karyawan Kontrak. Jakarta: Forum Sahabat.

Soewondo, Chandra. 2003. Outsourcing Implementasi di Indonesia. Jakarta: Elex MediaKomputindo.

Tambusai, Muzni. (2004). Pelaksanaan Outsourcing Ditinjau dari Aspek Hukum Ketenagakerjaan Tidak Mengaburkan Hubungan Industrial. Jurnal Informasi Hukum vol.1 Tahun VI.

Tunggal, Iman Sjahputra. (2009). Pokok-Pokok Hukum Ketenagakerjaan. Jakarta: Harvarindo.

Ropikhin, Esti. (2010). Penerapan Asas Kebebasan Berkontrak dalam Pembuatan Perjanjian Outsourcing dan Perjanjian Kerja Waktu Tertentu. 